\title{
Symptoms of depression in patients with cancer of the head and neck undergoing radiotherapy treatment: a prospective study
}

\author{
Juliana Maria de Paula ${ }^{1}$ \\ Helena Megumi Sonobe ${ }^{2}$ \\ Adriana Cristina Nicolussi ${ }^{3}$ \\ Márcia Maria Fontão Zago ${ }^{4}$ \\ Namie Okino Sawada ${ }^{4}$
}

\begin{abstract}
This study aimed to investigate the frequency of symptoms of depression in patients with cancer of the head and neck undergoing radiotherapy treatment, in the initial, middle and final stages of the treatment. This is a prospective exploratory quantitative study of 41 patients with head and neck cancer, undergoing radiotherapy treatment in the Oncology Outpatient Clinic of the Beneficência Portuguese Hospital of Ribeirão Preto. Data were collected through the Beck Depression Inventory instrument, and analyzed quantitatively by means of the Statistical Package for the Social Sciences. Symptoms of dysphoria were found to increase throughout the treatment, as well as the number of patients with depression. The results show the importance for the healthcare professionals to detect the prevalence and the levels of the symptoms of depression, since these symptoms tend to increase and may lead to consequences such as a lack of adherence to treatment and a decrease in the quality of life of these patients.
\end{abstract}

Descriptors: Radiotherapy; Depression; Head and Neck Neoplasms.

\footnotetext{
${ }^{1}$ Undergraduate student in Bachelor's and Teaching Diploma Program in Nursing, Escola de Enfermagem de Ribeirão Preto, Universidade de São Paulo, WHO Collaborating Centre for Nursing Research Development, Brazil. Scholarship holder of the Scientific Initiation Program at the Conselho Nacional de Desenvolvimento Científico e Tecnológico (CNPq).

${ }^{2}$ PhD, Professor, Escola de Enfermagem de Ribeirão Preto, Universidade de São Paulo, WHO Collaborating Centre for Nursing Research Development, Brazil.

${ }^{3}$ Doctoral student, Escola de Enfermagem de Ribeirão Preto, Universidade de São Paulo, WHO Collaborating Centre for Nursing Research Development, Brazil.

${ }^{4}$ Free lecturer, Associate Professor, Escola de Enfermagem de Ribeirão Preto, Universidade de São Paulo, WHO Collaborating Centre for Nursing Research Development, Brazil.
}

Corresponding Author: Juliana Maria de Paula Rua Mário Lamonato, 49 Jardim Morumbi CEP: 14680-000, Jardinópolis, SP, Brasil E-mail: jm_paula@hotmail.com 


\title{
Sintomas de depressão nos pacientes com câncer de cabeça e pescoço em tratamento radioterápico: um estudo prospectivo
}

Este estudo teve como objetivo identificar a frequência dos sintomas de depressão nos pacientes com câncer de cabeça e pescoço, em tratamento radioterápico, no início, meio e final do tratamento. Trata-se de estudo exploratório prospectivo, com abordagem quantitativa, de 41 pacientes com câncer de cabeça e pescoço, em tratamento radioterápico no Ambulatório de Oncologia do Hospital Beneficência Portuguesa de Ribeirão Preto. Os dados foram coletados por meio do instrumento inventário de depressão de Beck, e analisados de modo quantitativo, por meio do programa Statistical Package of Social Science. Conclui-se que os sintomas de disforia aumentaram ao longo do tratamento, assim como o número de pacientes com depressão. Os resultados mostram a importância de os profissionais da saúde detectarem a prevalência e os níveis dos sintomas de depressão, uma vez que esses sintomas tendem a aumentar, podendo levar a consequências como falta de aderência ao tratamento e diminuição da qualidade de vida desses pacientes.

Descritores: Radioterapia; Depressão; Neoplasias de Cabeça e Pescoço.

\section{Síntomas del depresión en los pacientes con cáncer de cabeza y cuello en tratamiento radioterápico: un estudio prospectivo}

\begin{abstract}
El objetivo de este estudio fue investigar la frecuencia de los síntomas de depresión en pacientes con cáncer de cabeza y cuello en el principio, medio y final del tratamiento radioterápico. Se trata de un estudio prospectivo, exploratorio y cuantitativo realizado con 41 pacientes con cáncer de cabeza y cuello en tratamiento de radioterapia en la Clínica de Oncología del Hospital Beneficencia Portuguesa de Ribeirão Preto. Los datos fueron recolectados a través del Inventario de Depresión de Beck y analizados cuantitativamente en el programa Statistical Package of Social Science. Como resultados se obtuvo los síntomas de disforia aumentaron durante el tratamiento, así como el número de pacientes con depresión. Los resultados muestran la importancia de los profesionales de salud en detectar los niveles y la prevalencia de síntomas de depresión, ya que estos síntomas tienden a aumentar y pueden llevar a consecuencias como la falta de adherencia al tratamiento y disminución de la calidad de vida de los pacientes.
\end{abstract}

Descriptores: Radioterapia; Depresión; Neoplasias de Cabeza y Cuello.

\section{Introduction}

The cancers of the head and neck represent the $6^{\text {th }}$ most common of all cancers. The estimation of cancer of the oral cavity, for the year 2010, according to the Ministry of Health(1) is 10,330 new cases in men and 3,790 in women. As head and neck surgery involves major resections, functional and aesthetic mutilations occur that impact in the daily life of patients. Another common treatment in this type of cancer is radiotherapy and chemotherapy which are used as adjuvants in order to inhibit metastasis and to improve the survival rate(2). The cancer treatments cause various physical and emotional collateral effects that impact in the daily life of the patient. Of all the symptoms anxiety and depression are the most prevalent psychological symptoms of cancer patients, with prevalence rate from 13 to $54 \%{ }^{(3-4)}$. According to these authors the variation is due to the different forms of measurement and heterogeneous samples.

The literature review ${ }^{(5)}$ showed that depression is the most common psychiatric disorder in patients with cancer, with a prevalence between 22 and 29\% depending on the location of the tumor, clinical stage, 
pain, functional and physical performance, and the existence of social support. Regarding head and neck cancer, a study ${ }^{(6)}$ was highlighted that estimated the prevalence of depression between 6 and $15 \%$ in contrast with rates of up to $40 \%$ found in studies in the 1980 's. A study carried out in the screening sector of the Head and Neck Surgery Service of the $\operatorname{INCA}^{(7)}$, found high levels of depressive symptoms in patients with head and neck cancer with a positive correlation in relation to the presence of pain. That is, the symptoms of depression present in patients with head and neck cancer may be related, among other causes, to the discomfort caused by the pain. In one study(5) the authors reported the difficulty in diagnosing depression in cancer patients, highlighting that it often goes undiagnosed due to lack of time to investigate the emotional issues, costs associated with the treatment, and mental health specialists and the oncologist working separately. Consequently, the depression is not treated, which leads to increased suffering in these patients, worsening the manifestation of cancer and impairing adherence to the treatment, leading to increased mortality. In another study $^{(8)}$ the authors conducted a systematic literature review on depression in elderly patients with cancer and highlighted the high prevalence of depressive disorders in cancer patients, especially the elderly, and the very low number of investigations into this. They found the rate of major depression to be moderate and that of minor depression to be high, and that they are accompanied by subliminal forms of depression that are at risk of not being recognized and not treated.

The person with cancer needs to adjust to their new identity as an oncological patient and needs to deal with the collateral effects of the radiotherapy, which can make the individual feel impotent in the face of their new condition ${ }^{(9)}$. It is very important to precisely evaluate the presence of symptoms of depression during the radiotherapy, in order to mitigate them and ensure good adherence of the patient to the treatment. Given the above, this study aimed to identify the frequency of symptoms of depression in patients with cancer of the head and neck undergoing radiotherapy treatment, in the initial, middle and final stages of the treatment.

\section{Methods}

This is an exploratory-descriptive, prospective, study with a quantitative approach. The exploratorydescriptive study, carried out between February 2009 and July 2010, was performed with the application of the Beck Depression Inventory, adapted in Brazil by Goreinstein(10). The study was conducted in the Specialized Oncology Center (CEON) of Ribeirão Preto - São Paulo. The CEON is part of the Beneficiência Portuguesa Hospital, where outpatient care is performed, through consultations, examinations, treatment and monitoring of adult patients with cancer originating from the Brazilian National Health System (SUS), from health insurance companies and the private sector of the city of Ribeirão Preto and the surrounding region.

The sample was comprised of 41 patients with head and neck cancer, undergoing radiotherapy treatment, who agreed to participate in the study and signed the terms of free prior informed consent. The inclusion criteria were: older than 18 years, diagnosed with cancer of the head and neck, treated at CEON, and in treatment at the time. Patients with other diagnoses and/or other cancers were excluded, as were those who had some mental deficit that could hinder the comprehension and/ or participation in the study and interviews. The research project was approved by a Research Ethics Committee and the anonymity of the patients was maintained according to the CONEP Resolution No. 196/96(11).

For the categorization of the patient data, an identification questionnaire was constructed to collect the socio-demographic data containing the variables: gender, age, marital status, origin, profession/ occupation, level of education and religion; clinical and therapeutic data; diagnosis; performance and type of surgery. The application of the instrument occurred during the first cycle of radiation therapy (Baseline), which evaluated the presence of symptoms of depression. The instrument was administered at the initiation (baseline), middle (approximately the $15^{\text {th }}$ session) and termination of treatment (after the $30^{\text {th }}$ session), to evaluate the presence of and changes in the symptoms of depression over the course of the radiotherapy treatment. All the patients in this sample completed the BDI at three times, with no loss of subjects due to death or prematurely ending their participation in the study. For the reading of the Beck Depression Inventory instrument, the criteria below were followed:

Beck Depression Inventory - Scale with 21 items that evaluate: 1) depressed mood, 2) pessimism, 3) sense of failure, 4) loss of satisfaction, 5) sense of guilt, $6)$ sense of punishment, 7) self-rancor (hatred, disgust), 8) self-accusation, 9) suicidal ideation, 10) crying, 11) irritability, 12) social isolation, 13) indecision, 14) altered body image, 15) inhibition for work, 16) sleep abnormalities, 17) fatigue, 18) loss of appetite, 19) weight loss, 20) somatic concerns, and 21) loss of libido. 
The scale is graduated in responses of 0 to 3 , where zero is the absence of the symptom and 3 the maximum presence of the symptom. The minimum score is 0 and the maximum is 63 . For the analysis of the cutoff point, a score of 0 to 15 was related to the absence of depression, 16 to 20 to dysphoria and from 21 to 63 to depression. For the data analysis, the Statistical Package for the Social Sciences (SPSS - version 15.0) was used and the Cronbach's Alpha test of internal consistency to test the reliability of the instrument. Descriptive statistical analysis was performed for the socio demographic and clinical analysis of the BDI.

\section{Results}

To test the internal consistency of the BDI in this sample, the Cronbach's alpha test was applied with the result $\alpha=0.91$, demonstrating that the instrument is reliable with this sample. Table 1 shows the demographic characteristics of the 41 patients with head and neck cancer undergoing radiotherapy, it was found that the majority of the patients came from the city of Ribeirão Preto $(46.3 \%)$ and the surrounding region (36.5\%), were predominantly male $(85.4 \%)$ and over 50 years of age $(82.9 \%)$.

Table 1 - Descriptive statistics of the sociodemographic characteristics

\begin{tabular}{lcc}
\hline \multicolumn{1}{c}{ Characteristics } & N & $\%$ \\
\hline Origin & 19 & 46.3 \\
$\quad$ Ribeirão Preto & 15 & 37 \\
Ribeirão Preto Region & 7 & 17 \\
Others & 41 & 100 \\
Total & & \\
State & 41 & 100 \\
São Paulo & 41 & 100 \\
Total & & \\
Age & 7 & 17.1 \\
30 I - 50 & 20 & 48.8 \\
$50 \mid-70$ & & (continue...)
\end{tabular}

Table 1 - (continuation)

\begin{tabular}{lcc}
\hline \multicolumn{1}{c}{ Characteristics } & N & $\%$ \\
\hline 70 I -90 & 14 & 34.1 \\
Total & 41 & 100 \\
Gender & & \\
Female & 6 & 14.6 \\
Male & 35 & 85.4 \\
Total & 41 & 100 \\
Profession & & \\
Work in the home & 6 & 14.6 \\
Retired & 17 & 41.5 \\
Security/Guard/Porter & 5 & 12.2 \\
Carpenter/mason/electrician & 4 & 9.7 \\
Farm worker & 9 & 22.0 \\
Total & 41 & 100 \\
Religion & & \\
Catholic & 34 & 82.9 \\
Evangelical & 4 & 9.8 \\
No religion & 3 & 7.3 \\
Total & 41 & 100 \\
\hline
\end{tabular}

Table 2 - Descriptive statistics of the clinical characteristics

\begin{tabular}{lcc}
\hline \multicolumn{1}{c}{ Characteristics } & N & $\%$ \\
\hline Diagnosis & 1 & \\
Parotid CA & 10 & 2.4 \\
Laryngeal CA & 30 & 73.2 \\
Hypopharynx/mouth/neck SCC & 41 & 100 \\
Total & & \\
Underwent surgery & 24 & 58.5 \\
Yes & 17 & 41.5 \\
No & 41 & 100 \\
Total & & \\
Underwent chemotherapy & 22 & 53.7 \\
Yes & 19 & 46.3 \\
No & 41 & 100 \\
Total &
\end{tabular}

Table 2 shows that the predominant diagnosis was squamous cell carcinoma of the hypopharynx, mouth and neck $(73.1 \%)$ and that the majority had undergone surgery $(58.5 \%)$ and chemotherapy (53.6\%).

Table 3 - Results of the BDI at the first, second and third application

\begin{tabular}{|c|c|c|c|}
\hline Beck Depression Inventory (values) & $\begin{array}{l}1^{\text {st }} \text { Application } \\
\text { Frequency (\%) }\end{array}$ & $\begin{array}{l}2^{\text {nd }} \text { Application } \\
\text { Frequency (\%) }\end{array}$ & $\begin{array}{l}3^{\text {rd }} \text { Application } \\
\text { Frequency }(\%)\end{array}$ \\
\hline$\leq 15$ & $33(80.5 \%)$ & $30(73.2 \%)$ & $28(68.3 \%)$ \\
\hline 16 to 20 & $05(12.2 \%)$ & $07(17.1 \%)$ & $09(21.9 \%)$ \\
\hline 21 to 63 & $03(7.3 \%)$ & $04(9.7 \%)$ & $04(9.8 \%)$ \\
\hline Total & $41(100 \%)$ & $41(100 \%)$ & $41(100 \%)$ \\
\hline
\end{tabular}

Table 3 shows that the symptoms of dysphoria increased throughout the treatment. At the initiation of the treatment only $12.1 \%$ of the patients had these symptoms and at the termination $21.9 \%$ of patients had 
symptoms of dysphoria. The proportion of patients with depression at the initiation was equal to $7.3 \%$ and $9.7 \%$ at the termination.

In order to check whether there was a statistically significant difference between the first and third application or the second and third application of the BDI, the Student's t-test for paired samples was performed with the results shown in Table 4.

Table 4 - Results of the Student's t-test for the BDI between the first and third applications, and the second and third applications

\begin{tabular}{ccccc}
\hline BDI & Mean & $\begin{array}{c}\text { Standard } \\
\text { deviation }\end{array}$ & $\begin{array}{c}\text { Student's } \\
\text { t-test }\end{array}$ & $\mathbf{p}$ \\
\hline BDI1 - BDI3 & -2.878 & 4.160 & -4.160 & 0.000 \\
BDI2 - BDI3 & -0.0707 & 3.716 & 1.219 & 0.230 \\
\hline
\end{tabular}

Table 4 shows that there was a statistically significant difference between the first and third applications, while between the second and third application there was no statistically significant difference, revealing that the changes in symptoms of dysphoria and depression were significant when considering the initiation and termination of treatment

\section{Discussion}

The socio-demographic characterization is consistent with the literature that demonstrates the higher incidence of head and neck cancer in males of the over 50 age group. The risk factors for cancer of the head and neck are associated with mutagenic and/or carcinogenic agents, originating from the environment, such as smoking, alcohol consumption, and genetic factors, which lead to a high incidence of this type of cancer in various countries Over $90 \%$ of the patients with head and neck cancer have a history of smoking and alcohol consumption. The inherent conditions of the individual, such as genetic susceptibility, may also alter this incidence, because not every smoker or alcohol user has the same risk of developing a tumor. Genetic susceptibility factors can be genetic polymorphism of enzymes that are able to metabolize carcinogenic agents; deficiency in the DNA repair mechanisms; the genetic characteristics related to sex and ethnic group; and familial susceptibility to cancer syndromes ${ }^{(12)}$.

In Brazil, patients with head and neck cancer have specific particularities that differ from neoplasms of other sites; the majority of these patients are in the over 50 age group and present associated diseases due to their poor general condition, as a result of changes caused by the disease itself and the socio-economic situation, along with numerous paraneoplastic syndromes ${ }^{(13)}$. The National Cancer Institute highlighted laryngeal cancer as one of the most common to affect the head and neck region, representing about $25 \%$ of the tumors that affect this area and $2 \%$ of all malignant diseases ${ }^{(1)}$.

The high incidence of laryngeal cancer in our study (24.4\%) resembles that also described in a study which presented the incidence of cancer of the largest cities in the State of São Paulo, especially the city of Ribeirão Preto which presented laryngeal cancer as one of the most common, with an incidence rate of $23.1 \%{ }^{(14)}$. The sample of the present study included patients from the region of Ribeirão Preto $(82.8 \%)$ with the occupation of farm workers $(21.9 \%)$. These results relate to the type of work in the region of Ribeirao Preto, where the monoculture of sugarcane offers an area of work for cane cutters, among which the consumption of high doses of liquor and tobacco is common, two risk factors for cancer of the head and neck. A study ${ }^{(15)}$ developed in the same region, also found similar results with respect to the labor occupation, demonstrating the predominance of retirees, followed by the categories farm worker, driver, guard, mason and electrician.

Depression, which in 2004 was the third leading cause of disease worldwide and a leader of disability in the high-income countries, can also adversely affect the course and outcome of chronic conditions such as cancer, diabetes and obesity ${ }^{(16)}$. The frequent association between depression and clinical illnesses, leads to a worse evolution both for the psychiatric conditions as well as for the clinical diseases, with lower adherence to the therapeutic guidelines as well as increased rates of morbidity and mortality ${ }^{(17)}$. In oncology, depression is associated with a decline in survival and adherence to treatment leading to a worse prognosis. Estimates indicate that approximately 10 to $25 \%$ of cancer patients present a major depressive disorder ${ }^{(18)}$. In the present study, from the middle of treatment, $17 \%$ of patients were found to have dysphoria, increasing to $21.9 \%$ at the termination of the treatment. It was also found that $9.75 \%$ of the patients had the presence of symptoms of depression at the termination of treatment. These data corroborate those of another study that found a $10.2 \%$ rate of depression in patients with breast cancer undergoing radiotherapy ${ }^{(19)}$. The frequency of symptoms of depression found in the present study was $7.3 \%$ at the initiation of radiotherapy and $9.7 \%$ in the middle and 
at the termination of the treatment, with a statistically significant difference; in another study ${ }^{(20)}$ the frequency of depressive symptoms was similar, at $7 \%$.

The serious collateral effects of the chemotherapy and radiotherapy treatments may be responsible for the increase in the symptoms of depression over time(21). The results of the present study highlight the need to evaluate the presence of symptoms of anxiety and depression throughout the radiotherapy treatment, as these symptoms tend to increase and may lead to consequences such as a lack of adherence to the treatment, a lower rate of survival and a decrease in the quality of life of the patients with head and neck cancer.

\section{Conclusions}

The socio-demographic characterization found in this study is consistent with the literature that demonstrates the higher incidence of head and neck cancer in males of the over 50 age group. Symptoms of depression are common in patients with cancer undergoing radiotherapy treatment. The data of the present study showed that there was an increase in symptoms throughout the treatment, the symptoms of dysphoria increased from $12.1 \%$ at the initiation of the treatment to $21.9 \%$ at the termination, whereas depression increased from $7.3 \%$ at the initiation of the treatment to $9.7 \%$ at the termination, with significant results between the first and third applications of the BDI.

Patients with head and neck cancer, undergoing oncological treatment, may develop symptoms of depression due to various factors related to the cancer itself and to the treatment. They may experience functional changes, such as difficulty breathing, swallowing, and impaired verbal communication, leading to social isolation and the adherence to treatment may be adversely affected. The use of instruments, such as the $\mathrm{BDI}$, in the quotidian practice with oncological patients undergoing radiotherapy treatment is important, so that the treatment becomes more effective since the symptoms of depression can be identified and evaluated throughout the course of treatment by the healthcare team in the non-psychiatric medical context, allowing the healthcare team to evaluate the mental health issues and propose interventions according to the needs of the patient, in order to improve their well-being and Quality of Life. The results of this study showed the importance of the healthcare professionals detecting the frequency and levels of depressive symptoms and planning actions that minimize these symptoms in order to improve the Quality of Life of patients with cancer of the head and neck undergoing radiotherapy treatment.

\section{References}

1. Ministério da Saúde (BR). Instituto Nacional do Câncer. A epidemiologia do câncer. Rio de Janeiro; 2010.

2. Lopes A, Iyeyasu H, Castro RMRPS. Oncologia para a graduação. São Paulo: Ed. Tecmedd; 2008.

3. Takahashi T, Hondo M, Nishimura K, Katani A, Yamano $\mathrm{T}$, Yanagita $\mathrm{H}$, et al. Evaluation of quality of life and psychological response in cancer patients treated with radiotherapy. Radiation Med. 2008;26(7):396-401.

4. Burguess C, Cornelius V, Love S, Graham J, Richards $M$, Ramirez A. Depression and anxiety in women with early breast cancer: five years observational cohort study. Br Med J. 2005;330(7493):702-6. doi:10.1136/ bmj.38343.670868.D3.

5. Bottino SM, Fráguas R, Gattaz WF. Depressão e câncer. Rev Psiq Clin. 2009; 36(3):109-15.

6. Archer J, Hutchison I, Korszun A. mood and malignancy: head and neck and depression. J Oral Pathol Med. 2008;37(5):255-70.

7. Bastos LW, Tesch RS, Denardin OVP, Dias FL. Níveis de depressão em portadores de câncer de cabeça e pescoço. Rev Bras Cir Cabeça Pescoço. 2007;36(1):125.

8. Spoletini I, Gianni W, Repetto L, Bria P, Caltagirone C, Bossú P, Spalletta G. Depression and cancer: An unexplored and unresolved emergent issue in elderly patients. J Oncol Hematol. 2008;65:143-55.

9. Muniz RM, Zago MMF. The oncologic radiotherapy experience for patients: a poison-drug. Rev. Latino-Am. Enfermagem. 2008;16(6):998-1004.

10. Goreinstein C, Andrade L. Validation of Portuguese version of Beck Depression Inventory and State-trait Anxiety Inventory in Brazilian subjects. Braz J Med Biol Res. 1996;29:453-7.

11. Ministério da Saúde (BR). Conselho Nacional de Saúde. Resolução CNS 196/96. Diretrizes e normas regulamentadoras de Pesquisas envolvendo seres humanos. Brasília: Ministério da Saúde; 1996.

12. Colombo J, Rahal P. Alterações genéticas em câncer de cabeça e pescoço. Rev Bras Cancerol. 2009;55(2):165-74.

13. Antunes AP. Princípios do planejamento terapêutico e avaliação geral do paciente oncológico. In: Carvalho MB. Tratado de cirurgia de cabeça e pescoço e otorrinolaringologia. São Paulo (SP): Atheneu; 2001. p. 21-9. 
14. Andreoni GI, Veneziano DB, Giannotti O Filho, Marigo C, Mirra AP, Fonseca LAM. Cancer incidence in eighteen cities of the State of São Paulo, Brazil. Rev Saúde Publica. 2001;35(4):362-7.

15. Alvarenga LS, Ruiz MT, Pavarino-Bertelli, Ruback JC, Managlia JV, Goloni- Bertollo M. Avaliação epidemiológica de pacientes com câncer de cabeça e pescoço em um hospital universitário do noroeste do estado de São Paulo. Rev Bras Otorrinolaringol. 2008;74(1):68-73.

16. Centers for Disease Control and Prevention. MMWR Morbidity and Mortality Weekly Report, Oct 1, 2010. [acesso 2 fev 2011]. Disponível em: http://www.cdc. gov/mmwr/pdf/wk/mm5938.pdf

17. Teng CT, Humes EC, Demetrio FN. Depressão e comorbidades clinicas. Rev Psiquitr Clin. 2005;32(3):149-59.

18. Croyle RT, Howland JH. Mood Disorders and cancer: a National Cancer Institute Perspective. Biol Psychiatry. 2003;54:191-4.

19. So WKW, Marsh G, Ling WM, Leung FY, Lo CKJ, Yeung $M$, et al. Anxiety, depression and quality of life among Chinese breast cancer patients during adjuvant therapy. Eur J Oncol Nurs. 2010;14:17-22.

20. Santos J, Mota DDCF, Pimenta CAM. Co- morbidade fadiga e depressão em pacientes com câncer colo-retal. Rev Esc Enferm USP. 2009;43(4):909-14.

21. Rao MR, Raghuram N, Nagendra HR, Gopinath KS, Srinath BS, Diwakar RB, et al. Anxiolytic effects of a yoga program in early breast câncer patients undergoing conventional treatment a randomized controlled Trial. Complem Ther Med. 2009;17(10):1-8. 